\title{
Pengaruh Jenis dan Dosis Pupuk Hayati Mikoriza terhadap Pertumbuhan dan Hasil Tanaman Cabai (Capsicum annuum L.) pada Tanah Andisol Lembah Seulawah Aceh Besar
}

\author{
Effect of Mycorrhizal Biofertilizer Type and Dosage Against Growth and Yield of Chilli \\ (Capsicum annuum L.) on Andisol Soil Valley in Aceh Besar
}

\author{
Ahmad Mizan Matondang ${ }^{1}$, Syafruddin $^{1}$, Jumini $^{1 *}$ \\ *Corresponding author: syafruddin@unsyiah.ac.id
}

\begin{abstract}
Abstrak. Penelitian ini bertujuan untuk mengetahui pengaruh jenis dan dosis pupuk hayati mikoriza yang tepat terhadap pertumbuhan dan hasil tanaman cabai merah pada tanah Andisol Lembah Seulawah Aceh Besar. Penelitian ini dilaksanakan di Kecamatan Lembah Seulawah, Kabupaten Aceh Besar, Rumah Kaca, Laboratorium Ilmu dan Teknologi Benih dan Laboratorium Fisiologi Tumbuhan Fakultas Pertanian Universitas Syiah Kuala, Darussalam Banda Aceh yang berlangsung sejak bulan Mei sampai dengan Oktober tahun 2019. Analisis data yang digunakan dalam penelitian ini adalah Rancangan Acak Kelompok pola Faktorial dengan kombinasi $3 \times 3$ dengan 3 ulangan sehingga didapat 9 kombinasi perlakuan dan mencakup 27 unit percobaan. Faktor yang diteliti yaitu jenis pupuk hayati mikoriza yang terdiri dari 3 taraf yaitu Glomus mosseae, Gigaspora sp. dan Campuran (Glomus mosseae dan Gigaspora sp.) dan dosis mikoriza yang terdiri dari 3 taraf yaitu 5,10 dan 15 g per tanaman dan dilanjutkan dengan uji lanjut Beda Nyata Terkecil pada taraf 5\%. Hasil penelitian menunjukkan bahwa perlakuan jenis mikoriza berpengaruh sangat nyata terhadap parameter diameter batang 15 HSPT dan panjang buah serta berpengaruh nyata pada tinggi tanaman 15 HSPT, diameter batang 45 HSPT, jumlah cabang produktif, berat buah, persentase kolonisasi mikoriza dan potensi hasil. Perlakuan jenis mikoriza dari pertumbuhan dan hasil tanaman cabai terbaik dijumpai pada jenis mikoriza campuran. Pada perlakuan dosis mikoriza berpengaruh sangat nyata terhadap parameter tinggi tanaman 30 dan 45 HSPT, diameter batang 30 HSPT, jumlah cabang produktif, berat basah tanaman, berat kering tanaman, berat basah akar, berat kering akar, berat buah, panjang buah, jumlah buah, persentase kolonisasi akar dan potensi hasil serta berpengaruh nyata pada diameter batang 45 HSPT. Perlakuan dosis mikoriza dari pertumbuhan dan hasil tanaman cabai terbaik dijumpai pada dosis mikoriza 10 $\mathrm{g}$ per tanaman. Terdapat interaksi yang nyata antara perlakuan jenis dengan dosis mikoriza terhadap jumlah cabang produktif tanaman cabai
\end{abstract}

Kata Kunci: Jenis Mikoriza, Andisol dan Dosis Mikoriza.

Abstract. This research aims to understand the type and doses of fertilizer biological mycorrhiza on growth and crop yield on the ground chili in the Andisol Seulawah valley Aceh Besar. This research was conducted in the Seulawah valley district of Aceh Besar, Greenhouse The Science and Technology Seeds and Laboratory of Plant Physiology, Syiah Kuala University Faculty of Agriculture Banda Aceh Darussalam held since october 2019. Data analysis used in this study is the random groups (shelf) factorials patterns by a combination with $3 \times 3$ test until they reached 9 combination treatment and 27 unit experiment. The research of fertilizer biological mycorrhiza consisting 3 kinds of standard that were Glomus mosseae, gigaspora sp. And blend (Glomus mosseae and gigaspora sp.) and dosage mycorrhiza consisting of 3 standard that were 5, $10,15 \mathrm{~g} /$ plant and continued with the Smallest Significant Difference test at the 5\% level. The results of this research were the treatment of mycorrhiza type had a very significant effect on plant height parameters stem diameter 15 DAP and fruit length and this research had a significant effect on plant height parameters 15 DAP, stem diameter 45 DAP, number of productive branches, fruit weight, percentage of root colonization and yield potential. The best mycorrhiza treatment of growth and yield of chili plants is found in mixed mycorrhiza types. In the treatment of dosage has a very significant effect on plant height parameters 30 and 45 DAP, stem diameter 30 DAP, number of productive branches, plant fresh weight, plant dry weight, root fresh weight, root dry weight, fruit weight, length fruit, number of fruits, percentage of root colonization and yield potential. The best mycorrhiza dose treatment of chili growth and yield was found on mycorrhiza dose of $10 \mathrm{~g}$ per plant. The interaction between the treatment of mycorrhiza types and dosage have a very significant on number of productive branches but not significant effect on other parameters.

Keywords: Types of Mycorrhizal, Andisols and Mycorrhizal Doses. 


\section{PENDAHULUAN}

Cabai merupakan tanaman perdu dari famili terong-terongan yang memiliki nama ilmiah Capsicum sp. Cabai berasal dari benua Amerika tepatnya daerah Peru dan menyebar ke negara-negara benua Amerika, Eropa dan Asia termasuk Negara Indonesia (Baharuddin, 2016). Produksi cabai merah di Aceh cenderung fluktuatif, pada tahun 2014 produksi mencapai 10,37 ton ha-1 dan pada tahun 2015 terjadi kenaikan sebesar 9,43\% menjadi 11,45 ton ha-1. Tahun 2016 angka produksi cabai merah di Aceh menurun menjadi 10,64 ton ha-1. Penurunan produksi cabai merah di Aceh pada tahun 2016 mencapai 7,08 \% dari tahun 2015. Produksi cabai di Aceh mengalami fluktuatif disebabkan teknik budidaya yang kurang tepat (BPS Aceh, 2017). Fluktuatifnya produktivitas cabai tersebut disebabkan oleh faktor tanah seperti pada tanah Andisol. Luas tanah Andisol di Indonesia mencapai 6,5 juta ha atau sekitar 3,4\% dari luas daratan (Nurmasyitah et al. 2013). Pemasalahan utama tanah Andisol saat ini yaitu retensi P yang tinggi (fosfat $>85 \%$ ) sehingga ketersediaan fosfat untuk tanaman rendah (Mukhlis, 2011). Salah satu upaya untuk meningkatkan produksi tanaman ialah dengan pemupukan, diantaranya penggunaan pupuk hayati mikoriza. Pupuk hayati mikoriza berfungsi sebagai biofertilizer dan bioprotektor untuk pertumbuhan dan produksi berbagai jenis tanaman (Syafruddin et al., 2012). Menurut Nurmasyitah (2013) setiap jenis mikoriza memiliki kemampuan yang berbeda-beda dalam aktivitasnya dengan tanaman. Mikoriza jenis Glomus mosseae merupakan jenis mikoriza yang lebih aktif pada tanah yang didominasi oleh fraksi lempung (clay), sedangkan pada mikoriza lainnya seperti Gigaspora sp. lebih aktif pada tanah berpasir. Penelitian yang dilakukan oleh Husin (1997) menunjukkan bahwa pemberiam mikoriza sebanyak $10 \mathrm{~g}$ pertanaman dapat meningkatkan serapan hara P pada tanaman yang bercekaman kekeringan. Hasil penelitian Syah et al, (2007) menyatakan bahwa penggunaan jenis dan dosis mikoriza dapat mempengaruhi peningkatan pertumbuhan dan produksi berbagai tanaman serta kualitas tanaman tanpa menurunkan kualitas dan produktivitas ekosistem tanah. Tujuan dari penelitian ini adalah untuk mengetahui jenis dan dosis mikoriza yang sesuai terhadap pertumbuhan dan hasil cabai merah yang di tanam pada tanah Andisol, serta interaksi antara keduanya.

\section{METODE PENELITIAN}

\section{Waktu dan Tempat}

Penelitian ini dilakukan di Kecamatan Lembah Seulawah, Kabupaten Aceh Besar, Rumah Kaca, Laboratorium Ilmu dan Teknologi Benih, Laboratorium Fisiologi Tumbuhan Fakultas Pertanian Universitas Syiah Kuala, Darussalam Banda Aceh. Pelaksanaan penelitian dimulai dari bulan Mei sampai dengan Oktober tahun 2019.

\section{Alat dan Bahan}

Alat yang digunakan dalam penelitian ini terdiri dari : cangkul, babybag (10 x 12 $\mathrm{cm}$ ), kertas label, gunting, sendok, meteran, jangka sorong, gembor, autoclave, aerator, terpal, ayakan 9 mesh, semprotan air, object glass, cover glass, saringan, ajir, plastik tahan panas $(5 \mathrm{~kg})$, mulsa plastik hitam perak, karet tahan panas, gelas ukur, timbangan analitik, mikroskop Nikon dengan pembesaran 100-400 kali, kamera dan alat tulis. Bahan yang digunakan terdiri dari: Benih cabai varietas Perintis (Lokal), pupuk hayati mikoriza jenis Glomus mosseae, Gigaspora sp., dan campuran (Glomus mosseae dan Gigaspora sp.), 
pupuk NPK (16-16-16), pupuk kandang, larutan $\mathrm{KOH}$, aquades, Larutan Trypan Blue 0,05\% (Quink Parker), insektisida berbahan aktif Imidakloprid dan Triazofos.

\section{Metode Penelitian}

Penelitian ini menggunakan Rancangan Acak Kelompok (RAK) pola faktorial 3 x 3 dengan 3 ulangan. Faktor pertama yaitu jenis mikoriza dan faktor kedua dosis mikoriza masing masing terdiri dari 3 taraf, sehingga diperoleh 9 kombinasi perlakuan dan jika diulang 3 kali akan diperoleh 27 unit percobaan. Pada setiap unit percobaan digunakan 4 sampel tanaman sehingga keseluruhan terdapat 108 satuan percobaan. Data hasil penelitian dianalisis menggunakan ANOVA. Apabila hasil uji F menunjukkan berpengaruh nyata $(\alpha=$ $5 \%$ ), maka dilanjutkan dengan Uji Beda Nyata Terkecil (BNT $\left.{ }_{0.05}\right)$.

\section{Pelaksanaan Penelitian}

\section{Perbanyakan Mikoriza}

Mikoriza yang digunakan pada penelitian ini yaitu mikoriza jenis Glomus mosseae, Gigaspora sp. dan campuran (Glomus mosseae + Gigaspora sp.) yang didapat dari hasil perbanyakan di Rumah Kaca Fakultas Pertanian Universitas Syiah Kuala.

\section{Persiapan Lahan}

Lahan yang digunakan untuk menanam cabai merah dibersihkan dulu dari gulma, kemudian tanah diolah dengan menggunakan cangkul dengan kedalaman 10-20 cm. Tanah yang telah dicangkul kemudian dibiarkan selama 2 minggu agar terjadi pertukaran udara dan membunuh patogen-patogen merugikan yang ada di dalam tanah. Selanjutnya dilakukan pembuatan plot yang bertujuan untuk mencegah akar tanaman tidak tergenang pada saat musim hujan. Plot dibuat dengan ukuran lebar $1 \mathrm{~m}$, panjang $18 \mathrm{~m}$, tinggi $40 \mathrm{~cm}$ dan jarak antar plot yaitu $50 \mathrm{~cm}$.

\section{Persiapan Benih}

Persiapan benih dilakukan dengan memperhatikan kualitas benih cabai merah yang akan digunakan yaitu memiliki daya berkecambah 90\%. Untuk proses perendaman dilakukan dengan menggunakan aerator selama 1 x 24 jam yang bertujuan untuk meningkatkan daya kecambah benih.

\section{Persiapan Pembibitan}

Benih yang digunakan dalam penelitian ini yaitu Perintis (Lokal). Kemudian benih disemai pada tanah Andisol dan pupuk kandang dengan perbandingan 2:1 yang dimasukkan dalam babybag ukuran $5 \mathrm{~cm}$ x $12 \mathrm{~cm}$. Diberikan mikoriza sebanyak 1/2 dosis dari 5, 10 dan $15 \mathrm{~g} \operatorname{tanaman}^{-1}$ sesuai dengan perlakuan jenis mikoriza kemudian benih ditanam satu benih per babybag.

\section{Pemberian Pupuk Kandang}

Pupuk kandang sebagai pupuk dasar diberikan sebelum pemasangan mulsa plastik hitam perak sebanyak $18 \mathrm{~kg}$ per bedengan atau setara dengan 10 ton ha-1. Pupuk kandang diberikan dengan cara menyebarkan pada setiap bagian bedengan atau dicampur rata dengan tanah.

\section{Pemberian Mulsa Plastik Hitam Perak}

Pemasangan mulsa dilakukan setelah bedengan selesai dibuat dan dipupuk. Kemudian mulsa dipasang dan dibuat lubang tanam sebanyak dua baris dalam setiap bedengan dengan jarak tanam $50 \mathrm{~cm}$ x $60 \mathrm{~cm}$ yang dilakukan secara zigzag. Mulsa yang 
digunakan 18 m untuk setiap bedengan. Jumlah bedengan 3, maka jumlah keseluruhan mulsa yang digunakan $54 \mathrm{~m}$.

\section{Pemberian Mikoriza dan Penanaman Bibit}

Pemindahan bibit ke lahan dilakukan pada umur 21 hari setelah penyemaian dengan kriteria memiliki 3-5 helai daun. Kemudian dibuat lubang tanam dengan kedalaman kurang dari $10 \mathrm{~cm}$. Pemberian $1 / 2$ dosis mikoriza sisa dari pembagian diawal pembibitan dan penanaman sesuai dengan kombinasi perlakuan. Penanaman bibit dilakukan sore hari untuk menghindari stres tanaman akibat panas matahari.

\section{Pemberian Pupuk NPK}

Pupuk NPK yang digunakan adalah 50\% dari dosis anjuran yaitu $125 \mathrm{~kg} \mathrm{ha}^{-1}$ atau $225 \mathrm{~g} \mathrm{plot}^{-1}$. Pemupukan dilakukan sebanyak 3 kali yaitu setelah pindah tanam, 21 hari setelah tanam (HST) dan 42 HST, sehingga setiap pemberian pupuk NPK diberikan sebanyak $75 \mathrm{~g}^{-1 t^{-1}}$ dengan cara melarutkan pupuk NPK dengan air sebanyak 15,84 L plot $^{-1}$ lalu disiramkan sebanyak $220 \mathrm{ml}$ tanaman $^{-1}$ pada area perakaran.

\section{Pemeliharaan}

Pemeliharaan tanaman cabai merah yang dilakukan yaitu penyulaman, penyiraman, penyiangan, pengajiran, pengendalian hama.

\section{Pemanenan}

Pemanenan dilakukan pada umur 90, 95, 100, 105, 110, 115 dan 120 HST dengan kriteria buah yang padat dan berwarna merah keseluruhan bagiannya. Pemanenan dilakukan dengan cara memetik buah beserta tangkainya bertujuan agar buah tetap segar dan tahan lebih lama ketika disimpan.

\section{Parameter Pengamatan}

\section{Tinggi Tanaman $(\mathbf{c m})$}

Pengamatan tinggi tanaman dengan cara mengukur dari pangkal batang utama hingga titik tumbuh tertinggi. Pengukuran tinggi tanaman dilakukan pada umur 15, 30 dan 45 HST.

\section{Diameter Batang (mm)}

Pengamatan diameter batang dilakukan pada umur 15, 30, dan 45 HST, dengan cara mengukur pada bagian pangkal batang tanaman cabai merah menggunakan alat jangka sorong.

\section{Jumlah Cabang Produktif (cabang)}

Pengamatan dilakukan dengan cara menghitung jumlah cabang tanaman yang menghasilkan bunga dan buah. Pengamatan dilakukan saat tanaman berumur 60 HST.

\section{Berat Basah dan Berat Kering Tanaman (g)}

Penimbangan berat basah tanaman dilakukan setelah panen ke 7 pada umur 120 HST. Berat kering tanaman ditimbang sesudah tanaman di oven selama 2 × 24 jam dengan suhu $60^{\circ} \mathrm{C}$ smapai berat konstan. Penimbangan dilakukan dengan menggunakan timbangan analitik.

\section{Berat Basah dan Kering Akar (g)}

Penimbangan berat basah akar dilakukan setelah berumur 120 HST. Berat kering akar tanaman ditimbang sesudah akar di oven selama $2 \times 24$ jam dengan suhu $60^{\circ} \mathrm{C}$. Penimbangan dilakukan dengan menggunakan timbangan analitik. 


\section{Berat Buah per Tanaman (g)}

Penimbangan berat buah per tanaman dilakukan setelah cabai merah dipanen hingga 7 kali pemanenan pada umur 90, 95, 100, 105, 110, 115 dan 120 HST. Penimbangan dilakukan menggunakan timbangan analitik.

\section{Panjang Buah (cm)}

Pengukuran panjang buah dilakukan setiap pemanenan, yaitu dengan mengambil 5 buah sampel setiap perlakuan selanjutnya nilai sampel dirata ratakan. Pengukuran dimulai dari pangkal sampai ujung buah dengan menggunakan meteran.

\section{Jumlah Buah per Tanaman (buah)}

Jumlah buah yang dihitung adalah buah yang dihasilkan pada setiap pemanenan. Perhitungan dilakukan dengan menjumlahkan seluruh hasil panen pertama sampai panen ke 7.

\section{Potensi Hasil (ton ha ${ }^{-1}$ )}

Potensi hasil dapat dihitung dengan cara mengkonversikan dari hasil berat buah per tanaman menggunakan rumus berikut :

$$
\text { Hasil }\left(\text { ton ha }{ }^{-1}\right)=\frac{1 \text { ha }-15 \%}{\text { Jarak tanam }} \times \text { Berat buah per tanaman }
$$

\section{Persentase Kolonisasi Akar Mikoriza (\%)}

Tanaman dicabut pada umur 45 HST untuk diamati persentase akar yang terkolonisasi mikoriza dengan menggunakan mikroskop elektron. Pengamatan dilakukan pada 9 sample per ulangan dengan menggunakan rumus (Schenck, 1982 dalam Nurhidayati et al., 2010).

$$
\text { Akar terkolonisasi }(\%)=\frac{\text { jumlah akar yang terkolonisasi mikoriza }}{\text { Jumlah akar yang diamati }} \times 100
$$

Lukitanigdyah (2013) mengemukakan bahwa untuk melihat ada tidaknya kolonisasi mikoriza pada sampel akar dilakukan perwarnaan akar dengan langkah-langkah sebagai berikut :

1. Tanaman yang diamati adalah tanaman sampel yang berumur 45 HST. Tanaman yang mendapatkan perlakuan dicabut dan diambil akarnya.

2. Akar tanaman dicuci dengan air aquades sampai bersih, kemudian dipotong-potong dengan ukuran 0,5-1 cm. Kemudian larutan $\mathrm{KOH} 10 \%$ dipanaskan pada suhu $60^{\circ} \mathrm{C}$ dan akar di rendam selama 10 menit yang gunanya untuk memutihkan akar.

3. Kemudian akar diwarnai dengan merendam dalam larutan Trypan Blue 0,05\% selama 24 jam. Setelah itu direndam kembali dalam aquades agar permukaan akar bersih dari pewarnaan biru.

4. Potongan akar dapat diamati di bawah mikroskop dengan pembesaran 100-400 kali. 


\section{HASIL DAN PEMBAHASAN}

\section{Pengaruh Jenis Mikoriza terhadap Pertumbuhan dan Hasil Tanaman Cabai Merah}

Berikut adalah rata-rata pengaruh jenis mikoriza terhadap pertumbuhan dan hasil tanaman cabai merah yang dapat dilihat pada Tabel 1 .

Tabel 1. Rata-rata Pengaruh Jenis Mikoriza terhadap Pertumbuhan dan Hasil Tanaman Cabai Merah.

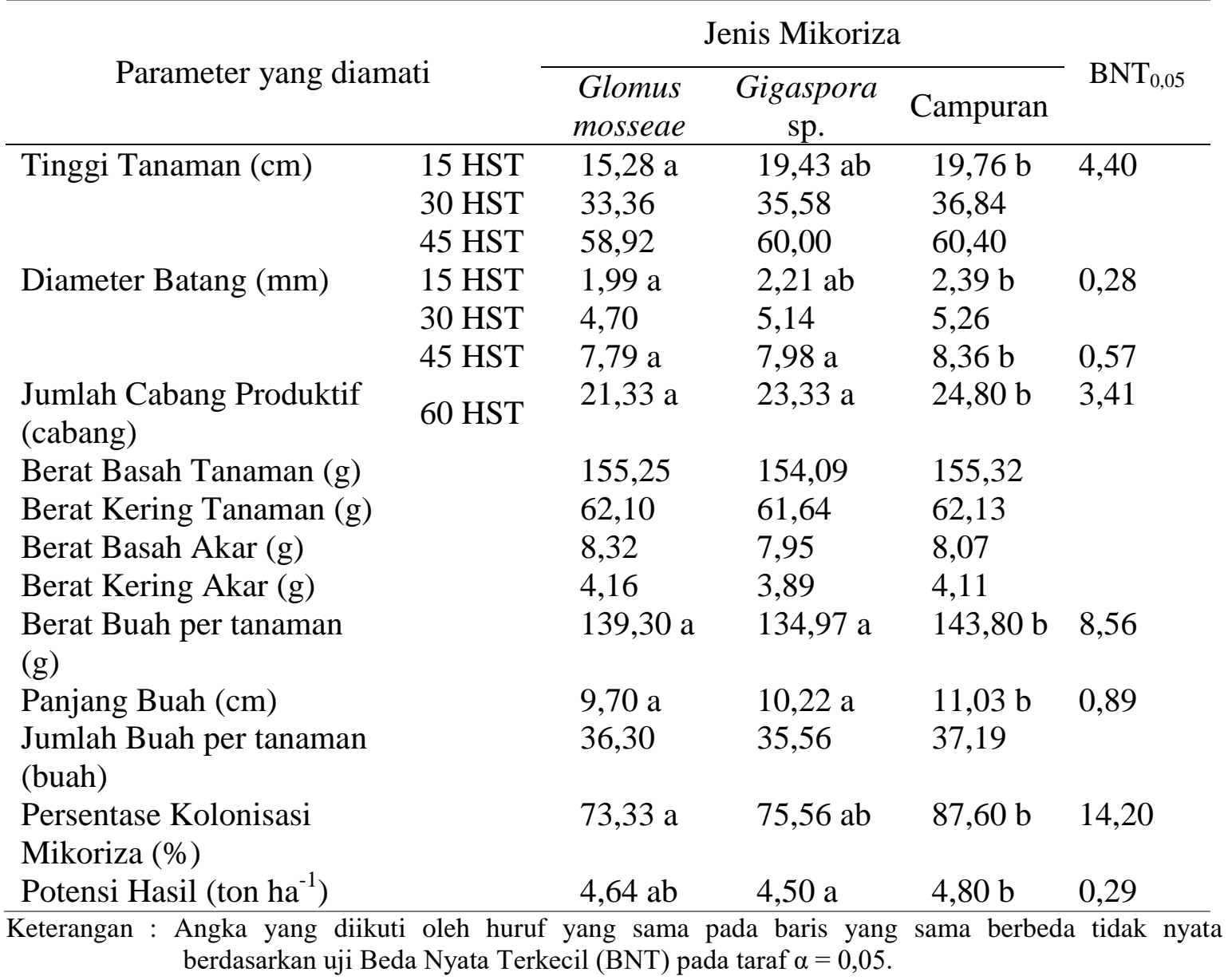

Tabel 1 menunjukan bahwa jenis mikoriza yang lebih baik terhadap pertumbuhan dan hasil tanaman cabai merah dijumpai pada jenis mikoriza Campuran (Glomus mosseae + Gigaspora sp.) terlihat pada tinggi tanaman 15 HSPT, diameter batang 15 dan 45 HSPT, jumlah cabang produktif, berat buah, panjang buah, persentase inokulasi mikoriza dan potensi hasil. Hal ini diduga karena perlakuan jenis mikoriza campuran lebih cocok dengan akar tanaman cabai dibandingkan jenis mikoriza yang lainnya dan juga mikoriza campuran sangat cocok digunakan di tanah Andisol karena mikoriza campuran dapat berkembang di tanah liat berpasir sehingga membantu pertumbuhan dan hasil tanaman cabai. Hal ini sejalan dengan pernyataan Yusnizar et. al. (2006) mendapatkan bahwa pertumbuhan akar tanaman kedelai yang diberikan pupuk hayati mikoriza Glomus mosseae dan Campuran cenderung lebih baik dibandingkan dengan jenis Gigaspora sp., kemudian pada hasil penelitian lainnya menyatakan bahwa penggunaan jenis dan dosis mikoriza dapat mempengaruhi peningkatan pertumbuhan dan produksi berbagai tanaman serta kualitas tanaman tanpa menurunkan kualitas dan produktivitas ekosistem tanah (Syah et al., 2007). 
Syafruddin et al. (2016) menyatakan bahwa mikoriza Campuran (Glomus dan Gigaspora) biasanya memiliki daya adaptasi dan pertumbuhan yang baik di daerah tercemar dan daerah tropis. Hal ini sesuai dengan hasil penelitian dari Syamsiyah et al. (2013), yang menyatakan bahwa serapan hara $\mathrm{N}$ dan $\mathrm{P}$ yang tinggi terdapat pada tanaman yang diberi mikoriza, disebabkan mikoriza akan mendorong berkembangnya hifa pada akar tanaman.

Jenis mikoriza yang terbaik berdasarkan parameter tinggi tanaman 15 HSPT, diameter batang 45 HSPT, jumlah cabang produktif, berat buah, panjang buah kolonisasi mikoriza dan potensi hasil, hal ini disebabkan jenis mikoriza campuran ini lebih unggul dalam penyerapan unsur hara $\mathrm{P}$ sehingga dapat meningkatkan hasil dan pertumbuhan tanaman cabai. Hal ini sejalan seperti pernyataan Yulianita (2011) kombinasi antara Glomus mosseae dengan Gigaspora sp. merupakan jenis mikoriza yang mempunyai penyebaran paling dominan dengan kemampuan simbiosis dan adaptasi lebih luas terhadap jenis tanaman budidaya jika dibandingkan dengan mikoriza tunggal.

\section{Pengaruh Dosis Mikoriza terhadap Pertumbuhan dan Hasil Tanaman Cabai Merah}

Tabel 2. Rata-rata Pengaruh Dosis Mikoriza terhadap Pertumbuhan dan Hasil Tanaman Cabai Merah.

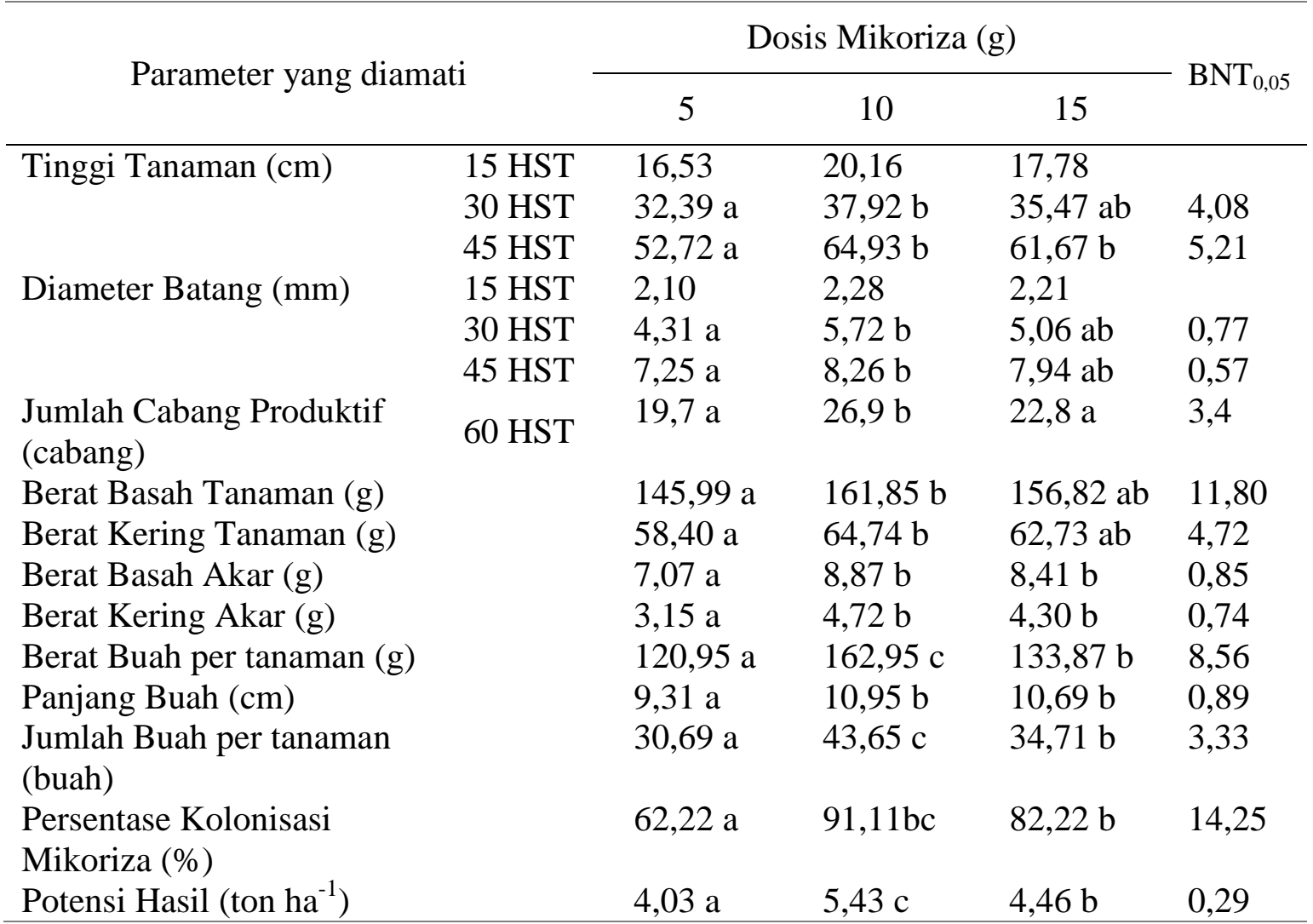

Keterangan : Angka yang diikuti oleh huruf yang sama pada baris yang sama berbeda tidak nyata berdasarkan uji Beda Nyata Terkecil (BNT) pada taraf $\alpha=0,05$.

Tabel 2 menunjukkan bahwa dosis mikoriza $10 \mathrm{~g}$ per tanaman berpengaruh baik terhadap parameter pertumbuhan dan hasil tanaman cabai kecuali pada parameter tinggi tanaman umur 15 HSPT dan diameter batang 15 HSPT. Hal ini terlihat dari parameter tinggi tanaman umur 30 dan 45 HSPT, diameter batang umur 30 dan 45 HSPT, jumlah 
cabang produktif, berat basah tanaman, jumlah buah pertanaman, berat buah pertanaman, panjang buah, jumlah buah, inokulasi akar dan potensi hasil pertanaman. Hal tersebut diduga perlakuan dosis mikoriza $10 \mathrm{~g}$ per tanaman sudah stabil dalam meningkatkan sejumlah parameter pertumbuhan dan hasil tanaman cabai dibanding dengan dosis lainnya, dikarenakan fungi mikoriza dapat membentuk banyak spora dan jalinan hifa apabila dosis mikoriza yang diberikan cukup dan sehingga dapat membantu penyerapan unsur hara dan air bagi tanaman. Hal ini sejalan dengan penelitian Azman (2016) yang menunjukkan bahwa dosis mikoriza $10 \mathrm{~g}$ per tanaman lebih baik terhadap pertumbuhan dan hasil tanaman cabai, yang ditunjukkan dari parameter berat basah tanaman, berat kering tanaman, berat buah pertanaman, jumlah buah, potensi hasil dan kolonisasi akar pada tanaman cabai. Pada hasil penelitian Zulaikha (2006) menyatakan bahwa pemberian dosis mikoriza yang tepat pada tanaman bisa menunjukkan respon yang signifikan, begitu juga sebaliknya pada dosis yang berlebihan akan menghambat pertumbuhan tanaman. Simbiosis antara akar tanaman dengan mikoriza selain meningkatkan penyerapan unsur hara juga mempengaruhi penyerapan air oleh tanaman (Ortas, 2010).

Parameter kolonisasi akar nilai tertinggi dijumpai pada dosis mikoriza $10 \mathrm{~g}$ per tanaman karena pada dosis 10 g per tanaman sesuai dengan kebutuhan tanaman dalam meningkatkan pertumbuhan dan hasil tanaman cabai. Hal ini sesuai dengan penelitian Syafruddin et al. (2017) yang menyatakan bahwa tingkat kolonisasi mikoriza dengan akar tanaman tertinggi dijumpai pada dosis mikoriza $10 \mathrm{~g}$ per tanaman, kemudian Akar yang terkolonisasi jamur mikoriza arbuscular akan semakin luas daya jelajahnya karena adanya hifa eksternal yang berkembang di luar akar, sehingga serapan hara tanaman meningkat (Syamsiyah et al., 2012) dan juga pada penelitian Djazuli (2011) menunjukkan bahwa perlakuan dosis mikoriza berpengaruh pada persentase kolonisasi akar tanaman oleh mikoriza, persentase kolonisasi mikoriza pada akar tanaman kedelai lebih tinggi terdapat pada dosis $10 \mathrm{~g} /$ tanaman, Aplikasi mikoriza meningkatkan jumlah populasi spora dan persentase kolonisasi mikoriza di dalam akar.

\section{Interaksi Antara Jenis dengan Dosis Pupuk Hayati Mikoriza terhadap Tanaman Cabai Merah}

Tabel 3. Rata-rata Pengaruh Interaksi antara Jenis dengan Dosis Pupuk Hayati Mikoriza terhadap Jumlah Cabang Produktif Tanaman Cabai Merah.

\begin{tabular}{clcccc}
\hline \multirow{2}{*}{ Parameter } & \multirow{2}{*}{ Jenis mikoriza } & \multicolumn{3}{c}{ Dosis Mikoriza } & \multirow{2}{*}{$\mathrm{BNT}$} \\
\cline { 2 - 4 } & & $5\left(\mathrm{D}_{1}\right)$ & $10\left(\mathrm{D}_{2}\right)$ & $15\left(\mathrm{D}_{3}\right)$ & \\
\hline \multirow{2}{*}{$\begin{array}{c}\text { Jumlah Cabang } \\
\text { Produktif } \\
\text { (cabang) }\end{array}$} & Glomus mosseae $\left(\mathrm{M}_{1}\right)$ & $15,33 \mathrm{Aa}$ & $23,67 \mathrm{Ab}$ & $25,00 \mathrm{Bb}$ & \\
\cline { 2 - 4 } & Gigaspora sp. $\left(\mathrm{M}_{2}\right)$ & $22,00 \mathrm{Ba}$ & $27,00 \mathrm{Bb}$ & $21,00 \mathrm{Aa}$ & 2,14 \\
& Campuran $\left(\mathrm{M}_{3}\right)$ & $21,66 \mathrm{Ba}$ & $30 \mathrm{Cb}$ & $22,33 \mathrm{Aa}$ &
\end{tabular}

Keterangan : Angka yang diikuti oleh huruf yang sama (Huruf kapital dilihat secara Horizontal dan Huruf Kecil dilihat secara Vertikal) Berbeda Tidak Nyata berdasarkan uji BNT pada taraf $\alpha=0,05$.

Tabel 3 menunjukkan bahwa pemberian berbagai jenis dan dosis mikoriza menunjukkan bahwa jumlah cabang produktif cabai yang terbaik terdapat pada kombinasi perlakuan jenis mikoriza campuran dengan dosis mikoriza $10 \mathrm{~g}$ per tanaman. Jenis mikoriza campuran dengan dosis $10 \mathrm{~g}$ dapat mendukung pertumbuhan tanaman cabai. 
Mikoriza campuran (Glomus mosseae dan Gigaspora. sp) memiliki tingkat adaptasi yang tinggi pada areal tercemar dan daerah tropis Syafruddin et al. (2012), inokulasi jamur mikoriza arbuskula juga dapat meningkatkan pertumbuhan dan kandungan klorofil cabai (Kim et al., 2009). Menurut Djazuli (2011), aplikasi mikoriza meningkatkan jumlah populasi spora dan persentase kolonisasi mikoriza di dalam akar. Fenomena ini juga terjadi pada mikroba tanah lainnya seperti rhizobium yang terdapat pada bintil akar tanaman kacang kacangan. Semakin banyak jumlah mikoriza maka semakin tinggi pula kemampuan mikoriza untuk mengkolonisasi akar tanaman, tetapi bila mikoriza diaplikasikan melewati batas toleran, maka persentase kolonisasi akar dan populasi spora mikoriza pada akar tanaman akan menurun. Faktor lingkungan juga mempengaruhi efektivitas mikoriza dalam mengkolonisasi akar. Hal-hal yang harus diperhatikan yaitu $\mathrm{pH}$, suhu, kadar air tanah, bahan organik tanah, ketersediaan hara, intensitas cahaya, logam berat dan fungisida (Syafruddin et al., 2016).

\section{KESIMPULAN DAN SARAN}

Jenis mikoriza berpengaruh sangat nyata terhadap diameter batang 15 HSPT dan panjang buah serta berpengaruh nyata pada tinggi tanaman 15 HSPT, diameter batang 45 HSPT, jumlah cabang produktif, berat buah, persentase kolonisasi mikoriza, potensi hasil. Dosis mikoriza berpengaruh sangat nyata terhadap tinggi tanaman umur 30 HSPT, diameter batang umur 30 dan 45 HSPT, jumlah cabang produktif, berat basah tanaman, berat kering tanaman, berat basah akar, berat kering akar, berat buah, panjang buah, jumlah buah pertanaman, persentase kolonisasi mikoriza, potensi hasil tanaman serta berpengaruh nyata pada tinggi tanaman 45 HSPT. Terdapat interaksi yang nyata terhadap jumlah cabang produktif. Kombinasi terbaik untuk pertumbuhan tanaman cabai dijumpai pada kombinasi jenis mikoriza campuran dengan dosis mikoriza $10 \mathrm{~g}$ per tanaman.

\section{DAFTAR PUSTAKA}

Azman, S. Syafruddin dan Jumini. 2016. Pengaruh aplikasi mikoriza campuran (Glomus mosseae dan Gigaspora sp.) terhadap pertumbuhan dan hasil beberapa varietas cabai (Capsicum annuum L.) pada tanah entisol. Skripsi. Fakultas Pertanian Universitas Syiah Kuala, Banda Aceh.

Badan Pusat Statistik dan Direktorat Jendral Hortikultura. 2019. Produksi Cabai merah Besar Menurut Provinsi Aceh 2012-2016. http://www.pertanian.go.id [2019].

Baharuddin, R. (2016). Respon Pertumbuhan dan Hasil Tanaman Cabai (Capsicum annum L.) Terhadap Pengurangan Dosis NPK 16 : 16 : 16 dengan Pemberian Pupuk Organik, XXXII, 115-124.

Djazuli, M. 2011. Pengaruh pupuk P dan mikoriza terhadap produksi mutu simplisia purwoceng. Bul. Littro, 22(2):147-156.

Husin, E. F. 1997. Respon beberapa jenis tanaman terhadap mikoriza vesikular arbuskular dan pupuk phosfat pada tanah Ultisol. hlm 4-8 didalam prosiding: Pemanfaatan Cendawan Mikoriza untuk Meningkatkan.

I. Ortas. Ozdemir, G., A. Akpinar, A. Sabir, H. Bilir, S and Tangolar (2010). Effect of Inoculation with Mycorrhizal Fungi on Growth and Nutrient Uptake of Grapevine Genotypes (Vittis sp.), European Journal of Horticultura Science,. 75(3), 103 - 110 
Kim K, Yim W, Trivedi P, Madhaiyan M, Boruah HPD, Islam MR, Lee G, Sa T. 2009. Synergistic effects of inoculating arbuscular mycorrhizal fungi and Methylobacterium oryzaestrains on growth and nutrient uptake of red pepper (Capsicum annuum L.). Plant and Soil. 327. (1-2):429-440

Lukitanigdyah, D. R. 2013. Tingkat persen kolonisasi propagul mikoriza vesikular arbuskula indigenous asal desa Pangpong kec. Labang kab. Bangkalan Madura pada perakaran tanaman padi (Oryza sativa), kedelai (Glycine max), dan tanaman gulma rumput teki (Cyperus rotundus). Paper. Institut Teknologi Sepuluh Nopember Surabaya, Surabaya.

Mukhlis. 2011. Tanah Andisol, Genesis, Klasifikasi, Karakteristik, Penyebaran dan Analisis. USU - Press. Medan.

Nurmasyitah., Syafruddin, dan M. Sayuthi. 2013. Pengaruh Jenis Tanah dan Dosis Fungi Mikoriza Arbuskular pada Tanaman Kedelai Terhadap Sifat Kimia Tanah. J. Agrista. 17 (3) :103-110.

Syafruddin and Efendi. 2012. Effect of provisioning bacterial isolates and NP fertilization on total microorganism and degradation level contaminated Inceptisol soil. Int. J. Agric. Res., $7: 449-456$.

Syafruddin S., S, Syakur dan Hasanuddin., . 2017. Teknik perbanyakan pupuk hayati mikoriza dan adopsi inovasi sebagai biofertiliser dan bioprotektor untuk peningkatan produksi cabai pada inceptisol krueng raya aceh besar. Laporan Akhir Penelitian Berbasis Kompetensi. Universitas Syiah Kuala. Banda Aceh.

Syafruddin S., S. Syakur and T, Arabia. 2016. Propagation techniques of mycorrhizal biofertiliser with different types of mycorrhizal inoculant and host plant in Entisol Aceh. Int. J.Agric. Res, 11 (2) : $69-76$.

Syah, J.M.A., I. Was dan Y. Herizal. 2007. Pemanfaatan Cendawan Mikoriza Arbuskula (CMA) untuk Memacu Pertumbuhan Bibit Manggis (Garcinia mangostana L.) Solok. Sinar Tani Edisi 24-30 Oktober 2007. Balai Penelitian Tanaman Buah Tropika.

Syamsiyah, J., Bambang, H. S., Eko, H dan Jaka, W. 2012. pengaruh inokulasi jamur mikoriza arbuskula terhadap glomalin, pertumbuhan dan hasil padi. Jurnal. Fakultas Pertanian. Universitas Gajah Mada. Yogyakarta.

Schenck. 1982. Taxonomy of fungi forming endomycorrhizal. In N.C. Schenck (eds.) Phytopat. Soc. St. Paul. Minnesota. Pp1-9.Universitas Gadjah Mada.Yogyakarta.

Yusnizar, Hifnalisa, dan Fikrinda. 2006. Populasi dan aktivitas mikroorganisme rhizosfer kedelai pada entisol akibat pemberian bahan organik dan pupuk hayati. Agrista. 52 : 1410-3389.

Zulaikha, S. 2006. Serapan fosfat dan respon tanaman tomat terhadap mikoriza dan pupuk fosfat terhadap tanah ultisol. J. bioshenia. 3 (2):83-92. 